\title{
Factors Associated with Hypovitaminosis D in People Living with HIV/AIDS (PLWHA) Followed up in Porto-Novo in 2019
}

\author{
Alassani Adébayo 1*, Gninkoun Comlan Jules², Mizèhoun-Adissoda Carmelle², \\ Dovonou C. Albert'1, Attinsounon Cossi1, Wanvoégbè Armand² \\ ${ }^{1}$ Medicine and Medical Specialties, Faculty of Medicine, University of Parakou, Parakou, Benin \\ ${ }^{2}$ Medicine and Medical Specialties, Faculty of Medicine, University of Abomey-Calavi, Abomey-Calavi, Benin \\ Email: *adebayoalassani@gmail.com
}

How to cite this paper: Adébayo, A., Jules, G.C., Carmelle, M.-A., Albert, D.C., Cossi, A. and Armand, W. (2021) Factors Associated with Hypovitaminosis D in People Living with HIV/AIDS (PLWHA) Followed up in Porto-Novo in 2019. Food and Nutrition Sciences, 12, 1020-1027.

https://doi.org/10.4236/fns.2021.1211075

Received: August 18, 2021

Accepted: November 13, 2021

Published: November 16, 2021

Copyright $\odot 2021$ by author(s) and Scientific Research Publishing Inc. This work is licensed under the Creative Commons Attribution International License (CC BY 4.0).

http://creativecommons.org/licenses/by/4.0/

\section{(c) (i) Open Access}

\begin{abstract}
Background: Vitamin D deficiency is very common among PLWHA compared to the general population and is promoted by several factors. Aim: To identify the factors associated with hypovitaminosis $\mathrm{D}$ in people living with HIV/AIDS (PLWHA) followed up in Porto-Novo in 2019. Methods: This was a cross-sectional, descriptive and analytical study. PLWHA who were monitored on an outpatient basis and who gave their consent were included in this work. Subjects unable to answer questions or under ongoing vitamin D supplementation or suffering from chronic liver diseases were not included. Hypovitaminosis D was defined by a blood level of 25 hydroxy-vitamin D less than $30 \mathrm{ng} / \mathrm{mL}$. Results: A total of 270 PLWHA were included in the study. The mean age of the patients was $39.51 \pm 6.85$ years with a female predominance $(73.3 \%)$. The frequency of hypovitaminosis D was $56 \%$. Hypertension, low protein intake, anemia and low glomerular filtration rate were associated with vitamin D deficiency. Conclusion: Vitamin D deficiency is common among PLWHA, which justifies routine screening, especially among those at risk.
\end{abstract}

\section{Keywords}

Hypovitaminosis D, PLWHA, Malnutrition, Denutrition, Porto-Novo

\section{Introduction}

Since the advent of highly active antiretroviral therapy in 1996, there has been an improvement in the quality of life and prognosis of HIV-infected individuals, as 
regards the decrease in the frequency of opportunistic diseases. Despite this significant improvement, HIV infection remains a public health problem. In 2018, 1.7 million new infections were recorded worldwide and 1 million deaths were due to HIV infection; the majority of these occur in developing countries [1]. This mortality is multifactorial including not only opportunistic conditions but also metabolic abnormalities such as vitamin D deficiency [2]. Indeed, vitamin D deficiency is very common among PLWHA compared to the general population with a prevalence that varies between $70 \%$ and $85 \%$ depending on the studies [3] [4]. Several factors promote this vitamin deficiency including low exposure to sunlight, low dietary intake of vitamin $\mathrm{D}$, alcohol consumption [3], chronic inflammation caused by the virus and antiretroviral treatment including protease inhibitors and non-nucleoside reverse transcriptase inhibitors [2]. Vitamin D deficiency is associated with high morbidity including bone, cardiovascular, metabolic [5] [6] [7] [8]. Several studies have reported the beneficial effects of a normal vitamin $\mathrm{D}$ level in the prevention of opportunistic conditions and thus the reduction of mortality [9] [10]. In Africa, studies on vitamin D deficiency in PLWHA are rare and non-existent in Benin. That's what justifies the present work whose aim is to identify the prevalence of vitamin D deficiency and its contributing factors.

\section{Patients and Method}

It was a transversal, descriptive and analytical study that took place from January 2 to February 5, 2019 at the Medical Center (MC) of Oganla in Porto-Novo. The study population consisted of PLWHA followed at this center. Outpatients PLWHA who gave their consent were included in this study. Subjects who were unable to answer questions or under ongoing vitamin D supplementation or who had chronic liver diseases were not included.

All patients followed up in the center who met the inclusion criteria were considered and it was a sampling by commodity.

Definition of variables: the dependent variable was hypo-25-hydroxy-vitamin $\mathrm{D}$ and the independent variables related to sociodemographic characteristics, lifestyle, history and comorbidities, nutritional status, dietary data and biological data (including hemoglobin, transaminases, creatinine and CD4 levels).

Hypo 25 hydroxy-vitamin D was defined by a blood level below $30 \mathrm{ng} / \mathrm{mL}$ [11] [12].

Physical inactivity was defined for a moderate intensity activity practice such as brisk walking less than 30 minutes.

Nutritional status was assessed by the body mass index (BMI) and interpreted as follows: underweight if BMI less than $18.5 \mathrm{Kg} / \mathrm{m}^{2}$; Normal BMI if between 18.5 and $24.9 \mathrm{Kg} / \mathrm{m}^{2}$; overweight if BMI between 25 and $29.9 \mathrm{Kg} / \mathrm{m}^{2}$; obesity if BMI greater than or equal to $30 \mathrm{Kg} / \mathrm{m}^{2}$.

The food intake was appreciated by the reminder of the 72 hours and the dietary needs appreciated by the Alimenthèque software; the daily energy intake 
was normal if it is equal to $\pm 200 \mathrm{kcal}$ of the calculated energy needs, the protein intake was considered low if it is less than $15 \%$ of the energy needs.

A daily consumption of fruits and vegetables less than 5 servings was considered low.

The glomerular filtration rate less than $60 \mathrm{ml} / \mathrm{min} / \mathrm{m}^{2}$ was considered low.

Data collection techniques: Data collection was done through an individual faceto-face interview followed by clinical examination, anthropometric data measurement, 72-hours recall, and bioassay.

Data processing and analysis: The data were entered into Epi info 3.5 and analyzed using Statistical Package for Social Sciences (SPSS) version 20.0. The Chi ${ }^{2}$ test was calculated. A p-value $<0.05$ was considered statistically significant.

Ethical aspects: the various measures taken before, during and after the collection of the data were the obtaining of an authorization from the administrative officials, the consent of the patients after explaining to them the purpose of the study and the role of vitamin D in the health of the population in general and more specifically in PLWHA and finally the respect of the confidentiality and anonymity of the results obtained.

\section{Results}

\subsection{General Characteristics of the Study Population}

A total of 270 PLWHA were included in the study. The mean age of the patients was $39.51 \pm 6.85$ years with a female predominance $(73.3 \%)$.

History and comorbidities were represented by tuberculosis, high blood pressure and diabetes in $14.4 \%, 18.9 \%$ and $3.3 \%$ respectively.

Lifestyle was characterized by alcohol consumption (58.9\%), physical inactivity $(55.6 \%)$, use of oral contraceptives (16.7\%), use of skin creams $(27.8 \%)$ and the practice of depigmentation (31.1\%). Therapeutically, $2.6 \%$ of PLWHA were on protease inhibitors and in $97.4 \%$ of cases Efavirenz was used (Table 1 ).

\subsection{Nutritional Status, Food and Biological Data}

Nutritionally 27 patients (10\%) were underweight. On the dietary level, a low energy intake was observed in $25.6 \%$ of patients and a low protein intake was present in $48.9 \%$ and all patients had a low consumption of fruits and vegetables.

Regarding biological abnormalities, anemia was noted in $45.9 \%$ of patients, a low glomerular filtration rate in $24.1 \%$ of cases and a CD $4<200 / \mathrm{mm}^{3}$ level in $55.6 \%$ of cases.

Among the respondents, 150 had a low vitamin D level, a prevalence of $55.6 \%$ with mean value of $27.24 \mathrm{ng} / \mathrm{mL}$ and extremes of 2 and $52.97 \mathrm{ng} / \mathrm{mL}$ (Table 2).

\subsection{Factors Associated with Hypovitaminosis D}

Factors associated with hypovitaminosis D in multivariate analysis were high blood pressure, anemia, low protein intake and low glomerular filtration rate (Table 3). 
Table 1. General characteristics of PHA followed in Porto-Novo in $2019(\mathrm{n}=270)$.

\begin{tabular}{|c|c|c|}
\hline & $\mathbf{n}$ & $\%$ \\
\hline \multicolumn{3}{|l|}{ age } \\
\hline$<40$ years & 144 & 53.3 \\
\hline$\geq 40$ years & 126 & 46.7 \\
\hline \multicolumn{3}{|l|}{$\operatorname{sex}$} \\
\hline Male & 72 & 26.7 \\
\hline Female & 198 & 73.3 \\
\hline \multicolumn{3}{|l|}{ complexion } \\
\hline tanned & 96 & 35.6 \\
\hline black & 174 & 64.4 \\
\hline \multicolumn{3}{|l|}{ History and comorbidities } \\
\hline tuberculosis & 39 & 14.4 \\
\hline High blood pressure & 51 & 18.9 \\
\hline diabetes & 9 & 3.3 \\
\hline \multicolumn{3}{|l|}{ Lifestyle } \\
\hline tobacco & 9 & 3.3 \\
\hline alcohol & 159 & 58.9 \\
\hline Physical inactivity & 150 & 55.6 \\
\hline Contraceptives & 33 & 16.7 \\
\hline Skin creams & 75 & 27.8 \\
\hline depigmentation & 84 & 31.1 \\
\hline \multicolumn{3}{|l|}{ Antiretroviral treatment } \\
\hline With protease inhibitors & 7 & 2.6 \\
\hline Treatment with Efavirenz & 263 & 97.4 \\
\hline
\end{tabular}

Table 2. Nutritional status, food and biological data of PHA monitored in Porto-Novo in $2019(\mathrm{n}=270)$.

\begin{tabular}{ccc}
\hline & $\mathrm{n}$ & $\%$ \\
\hline $\begin{array}{c}\text { Nutritional status } \\
\text { Underweight } \\
\text { normal }\end{array}$ & 27 & 10 \\
overweight & 123 & 45.6 \\
obesity & 90 & 33.3 \\
Food data & 30 & 11.1 \\
Low energy input & 69 & \\
Low protein intake & 132 & 25.6 \\
Insufficient consumption of \\
fruit and vegetables
\end{tabular}


Continued

\begin{tabular}{|c|c|c|}
\hline Biological data & & \\
\hline anemia & 124 & 45.9 \\
\hline Hepatic cytolysis & 57 & 21.1 \\
\hline Low glomerular filtration & 66 & 24.4 \\
\hline $\mathrm{CD} 4<200 / \mathrm{mm}^{3}$ & 150 & 55.6 \\
\hline Vitamin D deficiency & 150 & 55.6 \\
\hline
\end{tabular}

Table 3. Factors associated with vitamin D deficiency among PHAs followed in Porto-Novo in 2019 (Multivariate analysis).

\begin{tabular}{cccc}
\hline & gold & $95 \%$ CI & p \\
\hline High blood pressure & & & 0.04 \\
Yes & 7.56 & $1.15-49.6$ & \\
No & 1 & & 0.01 \\
\hline Low protein intake & 1 & & \\
Yes & 0.26 & $0.07-0.98$ & 0.02 \\
No & 1 & $0.03-0.70$ & \\
anemia & & & 0.03 \\
Yes & 0.14 & & \\
No & & $0.11-0.70$ & \\
\hline Glomerular filtration rate & 0.27 & & \\
low & & & \\
\hline
\end{tabular}

\section{Discussion}

The present study, which aimed at studying vitamin D deficiency in PLWHA, is one of the few conducted in Benin. At the end of this study, it appears that the prevalence of vitamin $\mathrm{D}$ deficiency in this population was $56 \%$ and that the factors associated with it were high blood pressure, anemia, low protein intake and low glomerular filtration rate...

The high prevalence of vitamin D deficiency found in our work is similar to that reported by Arnedo-Pena (45.1\%) [13]. In the general population, the prevalence of vitamin D deficiency is lower; in the study of Tangoh et al. [14] in Cameroon, and was 3.2\%. In USA, Pasquale M. et al. has reported a high prevalence of hypovitaminosis D among HIV-infected subjects ranging from 70.3 to 83.7\% [15].

The factors associated with vitamin $\mathrm{D}$ deficiency in the present study were similar to those found in the literature. Indeed, Magurno [16] and Fondio [17] respectively reported in their studies that high blood pressure was associated with vitamin $\mathrm{D}$ deficiency. The association between cardiovascular diseases and vitamin D deficiency has been explained by some authors. Indeed, In HIV-infected 
subjects atherogenesis is enhanced by several factors: HIV-induced chronic inflammation and immune activation (demonstrated by increased levels of proinflammatory cytokines and endothelial activation markers), excess of traditional risk factors, and antiretroviral drug-related dyslipidemia, hyperglycemia, central obesity, and lipodystrophy [18] [19] [20]. Vitamin D influences cardiovascular health by suppressing the renin-angiotensin system and stimulating cellular proliferation and differentiation via $1,25(\mathrm{OH}) 2 \mathrm{D}$ binding to vitamin $\mathrm{D}$ receptors in the heart, the endothelium, and the vascular smooth muscle [21] [22].

In addition, subjects with anemia were at increased risk of vitamin D deficiency according to Kumari et al. [23] and Mehta S et al. [24].

A low-protein diet associated with vitamin D deficiency was noted by Parva et al. [25]. Indeed, this low protein intake can promote undernutrition which is recognized as a factor associated with vitamin D deficiency [26] [27]. The association between decreased glomerular filtration rate i.e. renal failure and vitamin D deficiency was reported by Ali [28] and Singh [29]. This would be due at least in part, to the renal synthesis defect of $1 \alpha$ hydroxylase necessary for vitamin $\mathrm{D}$ metabolism. Moreover, chronic inflammation due to HIV infection and subsequent TNF- $\alpha$ overproduction may be responsible for renal $1 \alpha$-hydroxylase impairment, reducing the PTH (parathyroid hormone) stimulatory effect on the production of the hormonally active $1,25(\mathrm{OH}) 2 \mathrm{D}$ (1,25-dihydroxyvitamin $\mathrm{D}$ ) [15].

However, these findings are limited by the use of a cross sectional design.

\section{Conclusion}

Vitamin D deficiency is very common among PLWHA. The identified risk factors were high blood pressure, anemia, low protein intake and low glomerular filtration rate. Systematic screening for vitamin D deficiency should be done especially among those at risk to provide adequate care. A future study may assess the impact of vitamin D supplementation on the morbi-mortality of PLWHA with deficiency.

\section{Conflicts of Interest}

The authors declare no conflicts of interest regarding the publication of this paper.

\section{References}

[1] UNAIDS Data 2019 (2019) Jt United Nations Program HIV/AIDS. Geneva, 468 p. https://www.unaids.org/sites/default/files/media asset/2019-UNAIDS-data en.pdf

[2] Alvarez, N., Aguilar-Jimenez, W. and Rugeles, M.T. (2019) The Potential Protective Role of Vitamin D Supplementation on HIV-1 Infection. Frontiers in Immunology, 10, Article No. 2291. https://doi.org/10.3389/fimmu.2019.02291

[3] Jiménez-Sousa, M.Á., Martínez, I., Medrano, L.M., Fernández-Rodríguez, A. and Resino, S. (2018) Vitamin D in Human Immunodeficiency Virus Infection: Influence on Immunity and Disease. Frontiers in Immunology, 9, Article No. 458. 
https://doi.org/10.3389/fimmu.2018.00458

[4] Ncayiyana, J.R., Martinez, L., Goddard, E., Myer, L. and Zar, H.J. (2021) Prevalence and Correlates of Vitamin D Deficiency among Young South African Infants: A Birth Cohort Study. Nutrients, 13, Article ID: 1500. https://doi.org/10.3390/nu13051500

[5] D'Amelio, P. (2021) Vitamin D Deficiency and Risk of Metabolic Syndrome in Aging Men. The World Journal of Men's Health, 39, 291-301.

[6] Aibana, O., Huang, C.C., Aboud, S., Arnedo-Pena, A., Becerra, M.C., Bellido-Blasco, J.B., et al. (2019) Vitamin D Status and Risk of Incident Tuberculosis Disease: A Nested Case-Control Study, Systematic Review, and Individual-Participant Data Meta-Analysis. PLoS Medicine, 16, e1002907. https://doi.org/10.1371/journal.pmed.1002907

[7] Tenforde, W., Yadav, A. and Dowdy, W. (2017) Vitamin A and D Deficiencies Associated with Incident Tuberculosis in HIV-Infected Patients Initiating Antiretroviral Therapy in Multinational Case-Cohort Study. Journal of Acquired Immune Deficiency Syndromes, 75, e71-e79. https://doi.org/10.1097/QAI.0000000000001308

[8] Manion, M., Hullsiek, K.H., Wilson, E.M.P., Rhame, F., Kojic, E., Gibson, D., et al. (2017) Vitamin D Deficiency Is Associated with IL-6 Levels and Monocyte Activation in HIV-Infected Persons. PLoS ONE, 12, e0175517.

[9] Lee, J., Kim, J.Y., Kim, J., Mun, J.W. and Yeo, J.Y. (2021) Prevalence of and Risk Factors for Hypovitaminosis D in Patients with Rotator Cuff Tears. Clinics in Orthopedic Surgery, 13, 237-242.

[10] Caccamo, D., Ricca, S., Currò, M. and Lentile, R. (2018) Health Risks of Hypovitaminosis D: A Review of New Molecular Insights. International Journal of Molecular Sciences, 19, Article No. 892. https://doi.org/10.3390/ijms19030892

[11] Alzahed, R.A. (2018) The Prevalence of Hypovitaminosis D and Its Associated Risk Factors among Women of Reproductive Age in Saudi Arabia: A Systematic Review and Meta-Analysis. Clinical Medicine Insights. Women's Health, 11, 1-9. https://doi.org/10.1177/1179562X18767884

[12] Hussain, S. and Elnajeh, M. (2020) Prevalence and Risk Factors for Hypovitaminosis D among Healthy Adolescents in Kota Bharu, Kelantan. Journal of the ASEAN Federation of Endocrine Societies, 35, 176-180.

[13] Arnedo-Pena, A., Juan-Cerda, J.V., Romeu-Garcia, M., Sorribes-Segura, S., TiradoBalaguer, M., Gil-Fortun, M., et al. (2020) Vitamin D Status and Latent Tuberculosis Infection: Conversion in Nursing Homes, Spain. The International Journal of Tuberculosis and Lung Disease, 24, 278-286. https://doi.org/10.5588/ijtld.19.0365

[14] Tangoh, D.A., Apinjoh, T.O., Mahmood, Y., Nyingchu, R.V., Tangunyi, B.A., Nji, E.N., et al. (2018) Vitamin D Status and Its Associated Risk Factors among Adults in the Southwest Region of Cameroon. Journal of Nutrition and Metabolism, 2018, Article ID: 4742574. https://doi.org/10.1155/2018/4742574

[15] Mansueto, P., Seidita, A., Vitale, G., Gangemi, S., Iaria, C. and Cascio, A. (2015) Vitamin D Deficiency in HIV Infection: Not Only a Bone Disorder. BioMed Research International, 2015, Article ID: 735615. https://doi.org/10.1155/2015/735615

[16] Magurno, M., Crescibene, D., Spinali, M., Cassano, V., Armentaro, G., Barbara, K., et al. (2021) Vitamin D and Subclinical Cardiovascular Damage in Essential Hypertension. Endocrines, 2, 133-141. https://doi.org/10.3390/endocrines2020013

[17] Fondjo, L.A., Tashie, W., Owiredu, W.K., Adu-Gyamfi, E.A. and Seidu, L. (2021) High Prevalence of Vitamin D Deficiency among Normotensive and Hypertensive Pregnant Women in Ghana. BMC Pregnancy and Childbirth, 21, Article No. 331. 
https://doi.org/10.1186/s12884-021-03802-9

[18] Crowe, S.M., Westhorpe, C.L.V., Mukhamedova, N., Jaworowski, A., Sviridov, D. and Bukrinsky, M. (2010) The Macrophage: The Intersection between HIV Infection and Atherosclerosis. Journal of Leukocyte Biology, 87, 589-598. https://doi.org/10.1189/jlb.0809580

[19] Friis-Moller, N., Weber, R., Reiss, P., Thiebaut, R., Kirk, O. and d'Arminio Monforte, A. (2003) Cardiovascular Disease Risk Factors in HIV Patients-Association with Antiretroviral Therapy. Results from the DAD Study. AIDS, 17, 1179-1193. https://doi.org/10.1097/00002030-200305230-00010

[20] Galli, M., Ridolfo, A.L., Adorni, F., et al. (2002) Body Habitus Changes and Metabolic Alterations in Protease Inhibitor-Naive HIV-1-Infected Patients Treated with Two Nucleoside Reverse Transcriptase Inhibitors. Journal of Acquired Immune Deficiency Syndromes, 29, 21-31. https://doi.org/10.1097/00042560-200201010-00003

[21] Santoro, D., Gagliostro, G., Alibrandi, A., et al. (2014) Vitamin D Receptor Gene Polymorphism and Left Ventricular Hypertrophy in Chronic Kidney Disease. $\mathrm{Nu}$ trients, 6, 1029-1037. https://doi.org/10.3390/nu6031029

[22] Vaidya, A. and Williams, J.S. (2012) The Relationship between Vitamin D and the Renin-Angiotensin System in the Pathophysiology of Hypertension, Kidney Disease, and Diabetes. Metabolism: Clinical and Experimental, 61, 450-458. https://doi.org/10.1016/j.metabol.2011.09.007

[23] Kumari, S., Swetha, P., Krishnan, R.S., et al. (2021) The Association between Ferritin and Vitamin D Levels in Premenopausal Fibroid Uterus Cases with Anemia. Cureus, 13, e13392. https://doi.org/10.7759/cureus.13392

[24] Mehta, S., Mugusi, F.M., Spiegelman, D., et al. (2011) Vitamin D Status and Its Association with Morbidity including Wasting and Opportunistic Illnesses in HIVInfected Women in Tanzania. AIDS Patient Care and STDs, 25, 579-585. https://doi.org/10.1089/apc.2011.0182

[25] Parva, N.R., Tadepalli, S., Singh, P., et al. (2018) Prevalence of Vitamin D Deficiency and Associated Risk Factors in the US Population (2011-2012). Cureus, 10, e2741. https://doi.org/10.7759/cureus.2741

[26] Mendoza-Garcés, L., Velázquez-Alva, M.C., Cabrer-Rosales, M.F., Arrieta-Cruz, I., Gutiérrez-Juárez, R. and Irigoyen-Camacho, M.E. (2021) Vitamin D Deficiency Is Associated with Handgrip Strength, Nutritional Status and T2DM in Community-Dwelling Older Mexican Women: A Cross-Sectional Study. Nutrients, 13, Article No. 736. https://doi.org/10.3390/nu13030736

[27] Mokhtar, R., Holick, M., Sempértegui, F., Griffiths, J.K., Estrella, B., Moore, L., et al. (2017) Vitamin D Status Is Associated with Underweight and Stunting in Children Aged 6-36 Months Residing in the Ecuadorian Andes. Public Health Nutrition, 21, 1974-1985. https://doi.org/10.1017/S1368980017002816

[28] Ali, M., Ejaz, A., Solangi, S.A., et al. (2020) Vitamin D Deficiency in End Stage Renal Disease Patients with Diabetes Mellitus Undergoing Hemodialysis. Cureus, 12, e11668. https://doi.org/10.7759/cureus.11668

[29] Singh, A.K., Maurya, M.K., Baiswar, R. and Kumar, P. (2020) To Study Vitamin-D Insufficiency and Deficiency in Patients of Chronic Kidney Disease. Journal of Medical Science and Clinical Research, 8, 60-64. https://doi.org/10.18535/jmscr/v8i10.09 